without the vacuolated cell. Using Valonia and Nitella, marine and fresh-water algæ forms respectively, which have large enough cells to enable the sap to be collected from individual cells, they supply grounds for thinking that certain inorganic ions, for example potassium, are mainly, if not entirely, in solution in the sap of the vacuole, and yet retain a concentration much higher than that in the outside solution. The case of chlorides is particularly remarkable. Nitella will absorb practically every trace of chloride from the external solution, and will remain alive in distilled water for sixteen days without giving up any detectable trace of chlorine to the water, although containing very appreciable quantities in the vacuole. Hoagland concludes that Nitella under normal conditions possesses uni-directional permeability with reference to chlorine and potassium (Journ. Gen. Physiology, 5, pp. 629-646, I923).

Lapicque concludes that the simple doctrine of the semi-permeable membrane, as employed to explain the salt content and swelling properties of the living cell, will soon appear as inadequate as the astrological conception of the firmament which makes it a crystal vault studded with stars. He adumbrates as factors, in a more adequate explanation, the distribution of salts according to the Donnan equilibrium between a non-diffusible amphoteric colloid and an aqueous membrane, with the great sensitiveness of such an equilibrium to hydrogen ion concentration, and also the hydrophilic behaviour of lipoids, which varies with the proportion of cholesterin to fatty acids or to lecithin. In view also of the modification reported in mitochondria with changes in external medium, he suggests that account may have to be taken of the physiological rôle of these structures, at present almost exclusively studied by the cytologist. Finally, he points out that the protoplasm is the seat of continuous transformation of energy, and that the phenomena under consideration will not admit of solution in terms of a passive semi-permeable membrane. To this last point the supporters of the membrane may reply that they have always assumed that a living cell owes its semi-permeable properties to a living membrane.

\title{
Maori Ethnography. ${ }^{1}$
}

FOR more than half a century the New Zealand Institute has published in its Transactions a vast amount of valuable information upon all aspects of the history of a group of the most interesting islands in the world. In the earlier years of the Dominion few of the colonists were intimately acquainted with the native language, and fewer still could penetrate the veil that hides the thoughts and ideas of the Maori mind. Many of these ethnological contributions, therefore, are of doubtful reliability. They are, nevertheless, often quoted by anthropological writers in other countries who are unable to discriminate between the wheat and the chaff. After the New Zealand University, with its highly cultivated staffs in its various colleges, began to liberate on the colony graduates trained to careful observation and exposition, it was soon recognised that the scientific study of the native race was an undertaking of the utmost urgency, for the day was already far spent for the garnering of what remained of their rapidly vanishing traditions and beliefs.

New journals were therefore necessary for recording exclusively these anthropological data. The chief of these are the Journal of the Polynesian Society, the Bulletins of the Dominion Museum, and the Records of the Canterbury and Dunedin Museums. It is the tenth volume of the Dominion Museum Bulletins, by Mr. Elsdon Best, that now comes under notice. The author emphasises the qualifications with which any investigator of primitive peoples should be endowed. "No traveller," he says, " or he of short sojourns may delve into . . the inner strata of the mentality of barbaric man. . . ." [The Maori] "ever closely shields his true religion" " [and] ". . . his inner mentality from the inquisitive gaze and analytical probing of inquiring outsiders. . . . In order to open the pages of the inner life . . . of such folks it is highly necessary to gain his confidence. A long residence in their midst, a good knowledge of their language. A quiet and non-critical bearing; a heartfelt sympathy with the feelings and prejudices of the people."

Just such are the qualifications possessed by the author, and consequently he has attained to the position of one of the most trustworthy interpreters of Maori psychology, and one of the highest authorities on their customs and beliefs.

1 Maori Religion: Being an account of the Cosmogony, Anthropogeny, Religious Beliefs and Rites, Magic, and Folk-lore of the Maori Folk of New Zealand. Bulletin No. ro, Section r. By Elsdon Best. (Dominion Museum, Wellington, N.Z., I924.)
The section of the Bulletin we have before us, a closely printed report of 264 pages, incorporates a vast amount of new and valuable, but not easily compressible, matter. It is impossible to do more than summarise its parts (as Mr. Best superscribes his chapters). An introductory part deals with the definition, origin, and development of religion preliminary to a comparison with Maori religion; the second surveys Maori religion and mythology from the evidence of early writers. On this follows a lengthy account of Maori cosmogony, theogeny, and anthropogeny, and further, by a classification of their gods, correcting the mistakes of several ethnologists who have misunderstood the term god as applied to the Maori religion. The New Zealand natives, above all the Polynesians of the Pacific, recognise a supreme divinity-Io-possessing divine attributes more nearly akin to the European idea of godhead. Part five deals with the offerings, human sacrifices, and images by which their spiritual beings can be influenced. This is succeeded by 28 specially interesting pages on the functions of the priests, the sacred places, and divination. Many ethnologists will read with surprise the singular fact that the village latrine was a tuaha or sacred place. Tuaha is the word "applied to any place where men's hair is cut, where tapu food is cast away or offered to supernatural beings," ... and where "rites connected with many matters were conducted." The final part is concerned with an explanation of Maori ritual performances and formulæ-karakia - " a survey of native mentality and its effects as seen in the performance of rites connected with religion and magic," the numerous particulars of which " would require a chapter of cumbrous length " Mr. Best tells us, and so in the present Bulletin he can supply only a few illustrations. His work "The Maori," just about to be published, will, we hope, supply anthropologists with fuller details.

One suggestion may perhaps be permitted, that the numerous ritual formulæ quoted in the native language throughout the book and in several pages of addenda, might, if impossible of verbatim translation, be paraphrased to afford the reader, unacquainted with Maori speech, a general idea of their meaning. This monograph is of exceptional importance. So doubtless will be the second section, which will include a description of Maori magic and many illustrations of native myths and folk-tales. 